\title{
PENGABDIAN PADA MASYARAKAT PENGENALAN ALAT-ALAT LABORATORIUM FISIKA LANJUT BAGI GURU MGMP IPA SMP/MTS KABUPATEN BENGKAYANG
}

\author{
Anita $^{1}$, Dwi Fajar Saputri ${ }^{2}$, Nurhayati ${ }^{3}$, Wahyudi ${ }^{4}$, Nurussaniah ${ }^{5}$, \\ Lia Angraeni ${ }^{6}$, Handi Darmawan ${ }^{7}$ \\ 1,2,3,4,5,6Program Studi Pendidikan Fisika, Fakultas Pendidikan MIPA dan Teknologi, \\ ${ }^{7}$ Program Studi Pendidikan Biologi, Fakultas Pendidikan MIPA dan Teknologi, \\ IKIP PGRI Pontianak, Jalan Ampera No.88 Pontianak \\ 1e-mail: anitaummufaqih@gmail.com
}

\begin{abstract}
Abstrak
PPM kali ini mengangkat tema pengenalan alat-alat Fisika Lanjut Bagi Guru MGMP IPA/MTs Kabupaten Bengkayang. Hal ini didasarkan pada hasil studi yang menemukan bahwa ada diantara guru IPA SMP/MTs yang belum menguasai dan memahami alat-alat yang terdapat di dalam laboratorium IPA. Sehingga pemanfaatan alat-alat laboratorium IPA tersebut belum maksimal.Metode yang digunakan pada kegiatan PPM kali ini adalah dengan metode kolaboratif partisipatif. Metode ini merupakan penggabungan antara metode demonstrasi dan metode eksperimen. Dalam kegiatan ini, laboratorium Fisika IKIP PGRI Pontianak rancang menjadi 4 ruangan, yaitu mekanika (air track dan torsi), Fisika Modern, Elektronika digital dan Optika. Peserta yang hadir merupakan guru-guru yang tergabung pada MGMP IPA Kabupaten Bengkayang yang berjumlah 22 orang. Proses evaluasi kegiatan PPM dilakukan dengan memberikan angket kepada peserta. Hasil angket kepuasan peserta berkaitan dengan penyelenggaran PPM dengan nilai rata-rata 3.39 tergolong baik.
\end{abstract}

Kata Kunci: alat-alat laboratorium, fisika lanjut

\begin{abstract}
This time the PPM raised the theme of introducing Advanced Physics tools for Bengkayang District MGMP / MTs Teachers. This is based on the results of a study which found that there were among SMP / MTs science teachers who had not mastered and understood the tools contained in the science laboratories. So that the utilization of the science laboratory equipment is not maximal. The method used in this PPM activity is participatory collaborative methods. This method is a combination of demonstration methods and experimental methods. In this activity, the IKIP PGRI Pontianak Physics laboratory was designed to be 4 rooms, namely mechanics (water track and torque), Modern Physics, Digital Electronics and Optics. The participants who attended were 22 people who were members of the Bengkayang Regency Science MGMP. The process of evaluating PPM activities is done by giving questionnaires to participants. The results of the participant satisfaction questionnaire were related to the holding of PPM with an average value of 3.39 classified as good.
\end{abstract}

Keywords: laboratory equipment, advanced physics.

\section{PENDAHULUAN}

Laboratorium adalah salah satu standar sarana dan prasarana yang harus dipenuhi oleh setiap satuan pendidikan formal. Melalui berbagai program pemerintah telah berupaya memenuhi kebutuhan laboratorium Fisika di sekolah 
mulai dari pengadaan gedung, prasarana, peralatan dan bahan laboratorium serta penyiapan sumber daya manusia melalui pelatihan-pelatihan terhadap para guru tentang pengelolaan laboratorium.

Hasil studi tentang pengelolaan laboratorium fisika SMP di Kabupaten Bengkayang khususnya kepada guru yang tergabung pada MGMP IPA SMP/MTs Kabupaten Bengkayang menemukan beberapa kendala dan masalah dalam pengelolaan laboratorium fisika tersebut, diantaranya guru belum menguasai dan memahami berbagai alat laboratorium, minat dan motivasi guru untuk menggunakan laboratorium dalam pembelajaran kurang karena disebabkan pengetahuan, serta alat dan bahan laboratorium fisika belum tersusun dengan baik, sehingga mengalami kesulitan pada saat alat-alat laboratorium diperlukan.

Sejalan dengan permendiknas nomor 24 Tahun 2006 (Depdiknas, 2006) yang berkenaan dengan laboratorium, dosen program studi pendidikan fisika IKIP PGRI Pontianak dalam program tri dharma perguruan tinggi mencoba memfasilitasi kebutuhan guru dalam meningkatkan kompetensi guru tersebut. Salah satu pelatihan yang akan dilakukan adalah memberikan wawasan/pengetahuan kepada Guru IPA SMP/MTs tentang alat-alat laboratorium fisika lanjut.

Pada kegiatan ini, guru dikenalkan pada alat-alat yang digunakan pada percobaan fisika lanjut. Setelah guru mengenal alat-alat berserta fungsi dan cara kerjanya, diharapkan guru dapat membuat penuntun pratikum berdasarkan alatalat tersebut. Jika di sekolah tidak tersedia alat-alat yang standar, diharapkan guru dapat membuat atau mempergunakan alat-alat yang ada disekitar.

Berdasarkan penjelasan di atas diperlukan sebuah pelatihan yang dapat meningkatkan mutu guru dalam mengenal alat-alat fisika lanjut. Oleh sebab itu program Pengabdian Pada Masyarakat ini berjudul "Pengenalan Alat-alat Laboratorium Fisika Lanjut bagi Guru MGMP IPA SMP/MTs Kabupaten Bengkayang. 


\section{METODE}

Kegiatan Pengabdian Pada Masyarakat (PPM) Program Studi Pendidikan Fisika semester ganjil tahun ajaran 2017/2018 diselenggarakan di Laboratorium Fisika IKIP PGRI Pontianak Jalan Ilham Pontianak pada hari Kamis tanggal 14 September 2017. PPM Prodi Fisika kali ini mengangkat judul "Pengenalan Alatalat Laboratorium Fisika Lanjut bagi Guru MGMP IPA SMP/MTs Kabupaten Bengkayang". Peserta yang hadir adalah guru-guru yang tergabung pada MGMP IPA SMP/MTs Kabupaten Bengkayangberjumlah 22 orang. Guru-guru tersebut berasal dari seluruh guru SMP yang berada di Kabupaten Bengkayang yang tergabung ke dalam Musyawarah Guru Mata Pelajaran (MGMP) IPA SMP/MTs Kabupaten Bengkayang.Kegiatan PPM Prodi Fisika kali ini melibatkan 7 orang Dosen Prodi Fisika dan mahasiswa sebanyak 11 orang.

\section{Tahap Persiapan Pelaksanaan PPM}

Pada tahap ini, dilakukan rapat dalam pembentukan kepanitiaan PPM oleh program studi pendidikan fisika. Selanjutnya ketua panitia yang telah ditunjuk, menjelaskan pembagian tugas kepada masing-masing anggota sesuai dengan job description.

\section{Tahap Pelaksanaan}

Pelaksanaan kegiatan PPM dilakukan selama satu hari bertempat di laboratorium pendidikan fisika IKIP PGRI Pontianak yaitu laboratorium optika, laboratorium fisika dasar, laboratorium fisika modern dan laboratorium kelistrikan. Kegiatan dilaksanakan dengan metode demonstrasi dan eksperimen dengan pendekatan kegiatan dilakukan secara kolaboratif-partisipatif.

Teknis dilapangan adalah laboratorium yang digunakan sebanyak 4 buah dengan satu orang dosen sebagai koordinator yang akan dibantu oleh beberapa mahasiswa. Rincian sebagai berikut: (a) Laboratorium 1 Optika (difraksi) dipandu oleh Lia angraeni, S.Si., M.Pd, (b) Laboratorium 2 mekanika (air track) dipandu oleh Dwi Fajar Saputri, M.Pd., M.Si, (c) Laboratorium 3 Fisika Modern (Efek foto listrik dan konsep E/m) dipandu oleh Nurhayati, M.Pd., M.Si dan (d) Laboratorium Elektronika Digital dipandu oleh Anita, S.Pd., M.Si, serta peserta PPM akan diarahkan oleh Wahyudi, M.Pd., M.Si, yang bertindak sebagai Guide 
dari ruang pertemuan menuju ke setiap laboratorium fisika lanjut yang telah dipersiapkan

\section{Tahap Evaluasi}

Proses evaluasi yang dilakukan pada kegiatan PPM semester ganjil tahun ajaran 2017/2018 dilakukan melalui angket. Angket yang diberikan kepada peserta terdiri dari 14 soal dengan mengacu pada 6 indikator, yaitu: keahlian dan kesiapan fasilitator, kegunaan materi yang disampaikan, kesesuaian materi yang disampaikan dengan tema PPM, kesesuaian pelaksanaan kegiatan dengan harapan peserta, kesesuian waktu pelaksanaan, kesesuaian fasilitas yang diberikan pada saat pelaksanaan kegiatan.

\section{HASIL DAN PEMBAHASAN}

Pengabdian pada masyarakat (PPM) yang diselenggarakan oleh program studi pendidikan fisika pada semester ganjil tahun ajaran 2017/2018. PPM tersebut berjalan selama satu hari pada hari kamis tanggal 14 September 2017 di Laboratorium Fisika IKIP PGRI Pontianak Jalan Ilham Pontianak. Peserta yang hadir merupakan guru-guru yang tergabung pada MGMP IPA/MTs Kabupaten Bengkayang yang berjumlah 22 orang.

Seluruh peserta dipandu oleh seorang dosen yang menjadi Guide untuk memasuki setiap ruangan laboratorium yang telah disiapkan. Guide berfungsi mengarahkan para peserta dan menjelaskan secara umum tentang laboratorium Fisika yang ada di IKIP PGRI Pontianak. Gambar 1 dan 2 menunjukkan pengarahan yang diberikan Guide kepada peserta saat berada di laboratorium.

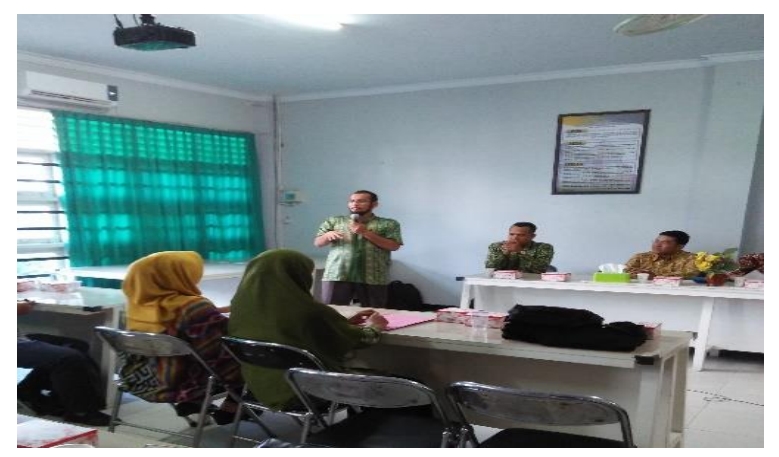

Gambar 1. Pengarahan awal kepada peserta sebelum memasuki ruangan laboratorium 


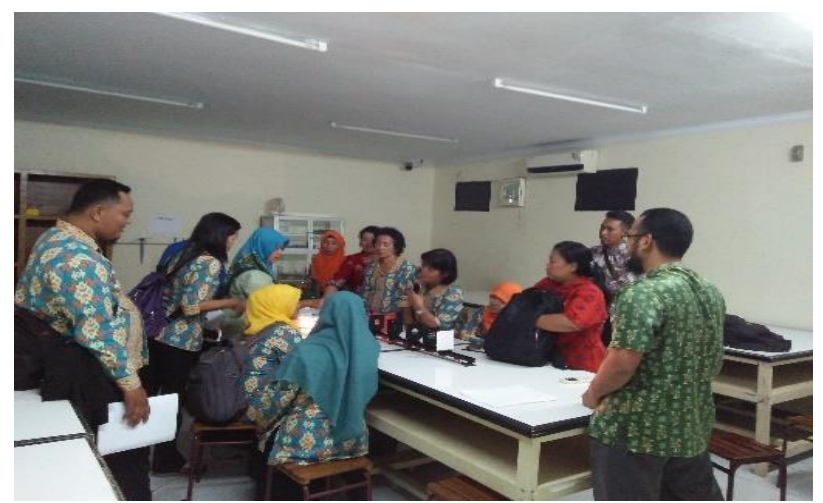

\section{Gambar 2. Pengarahan guide saat mengenalkan alat-alat laboratorium optika}

Pada saat peserta memasuki laboratorium Fisika Modern, peserta di berikan penjelasan mengenai alat efek foto listrik. Efek foto listrik adalah peristiwa terlepasnya electron dari permukaan logam karena logam tersebut disinari cahaya. Dosen menjelaskan nama-nama alat yang digunakan beserta fungsi-fungsinya. Apabila sebuah tenaga gelombang elektromagnetik/foton yang terkuantisasi dikenakan pada suatu logam maka elektron dapat terlepas dari logam. Bila tenaga foto tepat sama dengan fungsi kerja logam yang dikenainya maka tidak akan terjadi pelepasan elektron dan jika lebih besar frekuensi foton terhadap frekuensi ambang logamnya maka akan terjadi pelepasan elektron, yang biasa disebut efek fotolistrik (Septiadiah,2011). Hal tersebut dapat dilihat pada Gambar 3 berikut:

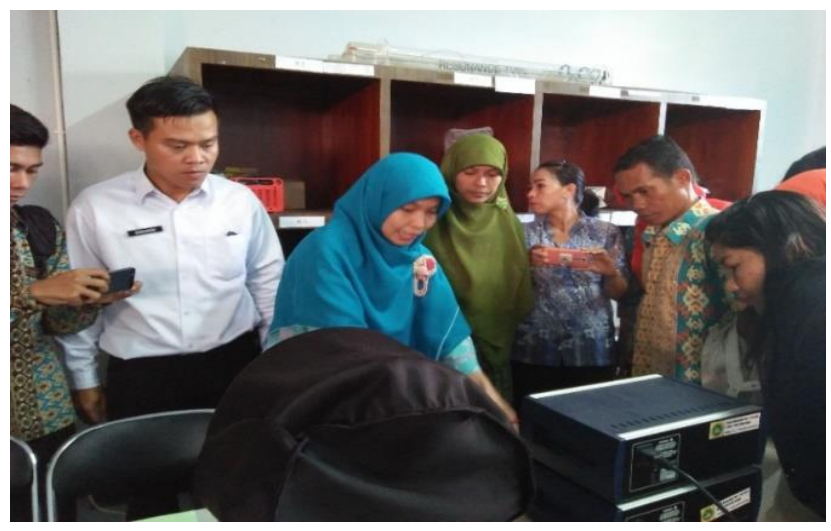

\section{Gambar 3. Dosen menjelaskan nama dan fungsi alat pada Efek Foto Listrik}

Setelah dosen menjelaskan nama dan fungsi alat pada efek foto listrik, kemudian peserta diberikan kesempatan untuk melakukan percobaan untuk pengambilan data dengan mengubah-ubah tegangan dan arus yang masuk. Sehingga akan muncul loncatan elektron mulai dari setitik cahaya hingga 
membentuk lingkaran penuh cahaya yang berwarna biru, hal ini yang dilakukan oleh Hallwachs pada tahun 1888, bahwa suatu keping yang netral akan memperoleh muatan positif apabila disinari. Kesimpulan yang dapat ditarik dari pengamatan-pengamatan di atas adalah bahwa cahaya ultraviolet mendesak keluar muatan litrik negatif dari permukaan keping logam yang netral seperti Gambar 4 berikut:

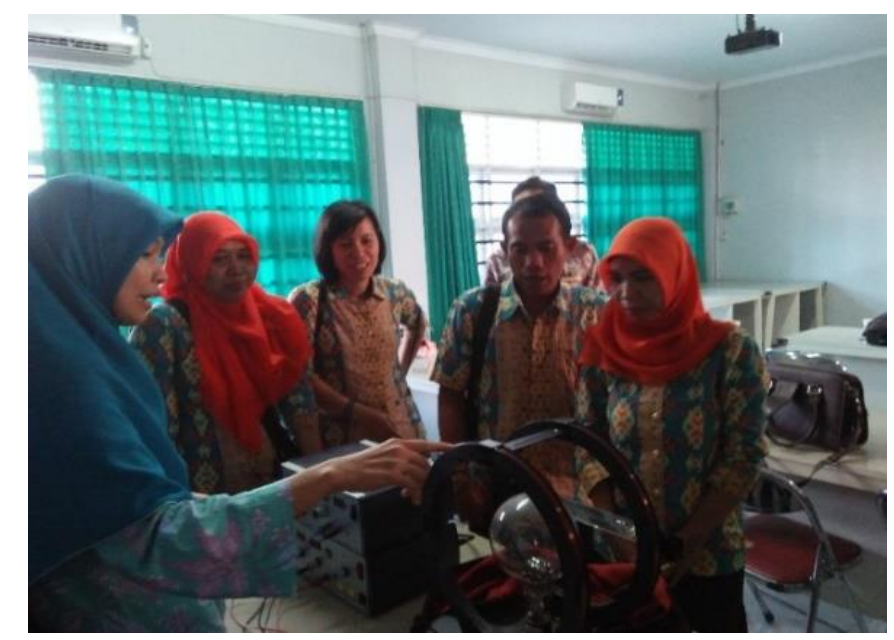

\section{Gambar 4. Saat peserta mencoba menggunakan alat fisika modern}

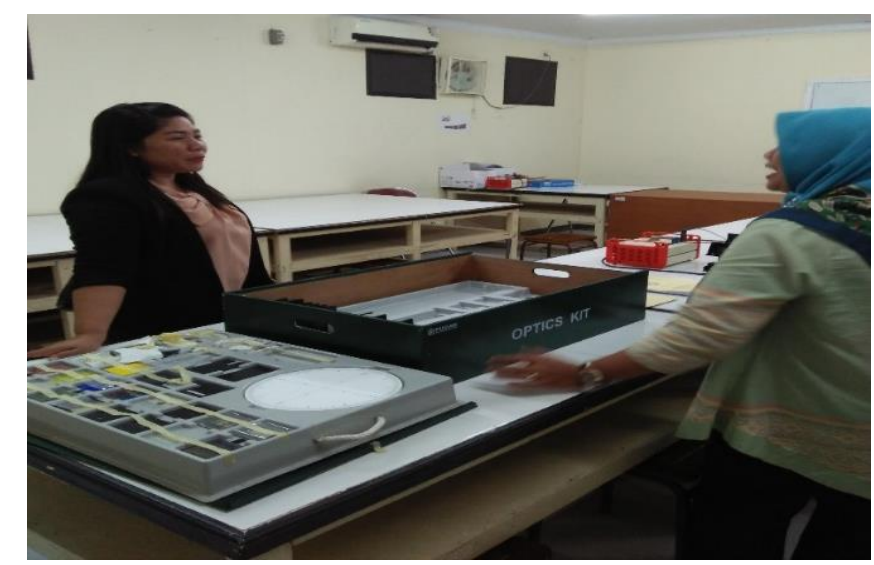

\section{Gambar 5. Dosen menjelaskan nama dan fungsi alat pada difraksi cahaya}

Setelah peserta mencoba di laboratorium fisika modern, peserta di berikan kesempatan untuk menuju ke laboratorium Optika. Di laboratorium Optika tersebut, peserta dikenalkan pada alat-alat yang berkenaan dengan konsep difraksi cahaya Seperti terlihat pada Gambar 5. Dosen menjelaskan konsep difraksi merupakan gejala pembelokan cahaya bila mengenai suatu celah sempit. Semakin 
sempit celah yang dilalui cahaya, semakin dapat menghasilkan perubahan penjalaran cahaya yang semakin lebar. Penghalang ini hanya dapat meneruskan sebagaian kecil dari gelombang yang dapat melalui lubang celah dapat terus sedangkan yang lain akan berhenti atau akan kembali.

Pada kegiatan selanjutnya adalah para peserta diberikan kesempatan untuk melakukan berbagai percobaan mengenai difraksi cahaya, peserta kegiatan membuktikan bahwa cahaya masuk melalui celah yang cukup lebar akan membentuk bayangan geometris pada layar (Gambar 6). Bagian yang terang persis sama lebar dengan panjang celah. Di luar bagian yang terang adalah bayangan geometris. Apabila celah dipersempit, maka bagian yang terang pada layar akan melebar ke daerah bayangan geometrisnya.

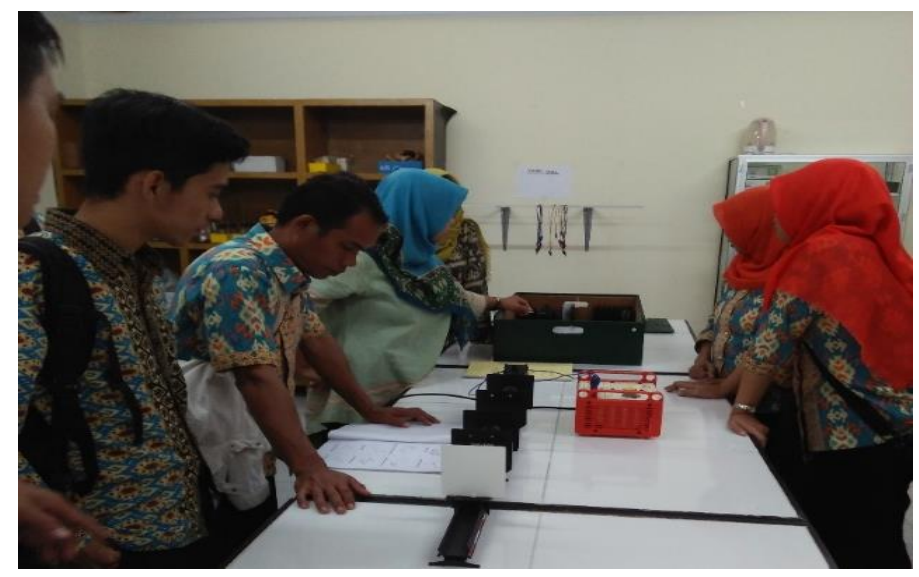

\section{Gambar 6. Peserta mencoba melakukan percobaan difraksi cahaya}

Proses evaluasi kegiatan PPM dilakukan dengan memberikan angket kepada peserta. Angket yang berbentuk skala likert kemudian dihitung dan dianalisis. Berdasarkan hasil penilaian/tanggapan peserta setelah mengikuti kegiatan PPM diperoleh rata-rata sebesar 3.39 dengan kriteria tergolong baik. Secara lengkap dapat di lihat pada Tabel 1 berikut: 
Tabel 1 Hasil Angket Peserta PPM Prodi P.FisikaTA 2017/2018

\begin{tabular}{lcc}
\hline \multicolumn{1}{c}{ Indikator } & Nilai & Kriteria \\
\hline $\begin{array}{l}\text { 1. Keahlian dan kesiapan fasilitator. } \\
\text { 2. Kegunaan materi yang disampaikan. }\end{array}$ & 3.5 & Sangat Baik \\
\hline $\begin{array}{l}\text { 3. Kesesuaian materi yang disampaikan } \\
\text { dengan tema PPM. }\end{array}$ & 3.6 & Sangat Baik \\
\hline $\begin{array}{l}\text { 4. Kesesuaian pelaksanaan kegiatan dengan } \\
\text { harapan peserta. }\end{array}$ & 3.2 & Baik \\
\hline $\begin{array}{l}\text { 5. Kesesuian waktu pelaksanaan } \\
\text { 6. Kesesuaian fasilitas yang diberikan pada }\end{array}$ & 3.4 & Baik \\
$\quad$ saat pelaksanaan kegiatan & 3.3 & Baik \\
\hline \multicolumn{1}{c}{ Rata-rata }
\end{tabular}

Berdasarkan Tabel.1 dapat diketahui untuk tiap indikator ketercapaian pelaksanaan PPM rata-rata berkategori baik. Hal ini berarti proses kegiatan PPM Prodi Pendidikan Fisika secara keseluruhan berjalan sesuai dengan yang direncanakan serta mendapat apresiasi yang baik dari para peserta, yaitu guru yang tergabung pada MGMP IPA SMP/MTs Kabupaten Bengkayang.

Pada indikator keahlian dan kesiapan materi dan indikator kesesuaian materi yang disampaikan dengan tema PPM tergolong sangat baik. Hal ini berarti dosen yang menjadi pembimbing dengan tema yang diangkat adalah pengenalan alat-alat dan fungsi-fungsi fisika lanjut dapat memberikan penjelasan yang baik kepada guru. Sehingga guru menjadi puas terhadap pelaksanaan kegiatan yang diselenggaran tersebut.

Untuk indikator kegunaan materi yang disampaikan, kesesuaian fasilitas yang diberikan pada saat PPM, kesesuaian pelaksanaan pelatihan dengan harapan peserta dan indikator kesesuaian waktu tergolong baik. Hal ini berarti alat-alat laboratorium yang digunakan untuk praktik dapat berfungsi sebagaimana mestinya. Sehingga apa yang menjadi harapan peserta berkenaan dengan tujuan untuk mengikuti kegiatan PPM ini dapat tersalurkan. Pada kegiatan ppm ini guru juga diberikan kesempatan untuk mencoba berbagai alat-alat laboratorium fisika 
lanjut, sehingga peserta dapat lebih memahami konsep yang disampaikan. Karena peserta mengalami sendiri dan membuktikan sendiri konsep-konsep yang biasanya hanya dipelajari secara teori saja. Sejatinya pembelajaran yang bermakna adalah pembelajaran yang melibatkan secara lanjut para peserta didik.

Sehingga secara keselurahan kegiatan PPM ini dapat dikatakan memberikan kontribusi kepada guru dalam mengenalkan alat-alat fisika lanjut, khususnya pda Fisika Modern dan Fisika Optika. Dengan guru mengenal alat-alat yang ada di laboratorium Fisika, diharapkan guru dapat memanfaatkan ketersediaan alat-alat laboratorium yang ada di sekolah dalam proses belajar mengajar. Sehingga mempermudah siswa dalam memahami konsep-konsep IPA/Fisika yang dipelajari.

Selain itu, dengan kegiatan PPM Prodi Pendidikan Fisika diharapkan dapat memberikan tambahan wawasan kepada guru khususnya pada pratikum dan pengelolaan pada materi Fisika Lanjut. Hal ini berdasarkan Suseno dan Riswanto (2017), menyatakan bahwa minat dan motivasi guru masih kurang dalam penggunaan laboratorium dalam pembelajaran serta laboran/guru belum menguasai dan memahami berbagai alat.

Pada kegiatan PPM kedepannya diharapkan prodi pendidikan fisika dapat memberikan kontibusi berupa pembimbingan kepada peserta guru pada materi dan konsep-konsep fisika yang lainnya. Serta adanya pertukaran informasi berupa apa yang saat ini dibutuhkan pihak sekolah/siswa sehingga dapat dicarikan alternative/solusi secara bersama. Dengan demikian kolaborasi antar guru dan dosen tetap terjalin, informasi kebutuhan sekolah tidak putus tetapi dapat dipenuhi oleh pihak program studi pendidikan fisika sebagai lembaga yang akan mencetak calon guru fisika.

\section{UCAPAN TERIMA KASIH}

Pengabdian pada masyarakat ini terselenggarakan berkat bantuan dana APBS IKIP PGRI Pontianak tahun akademik 2017/2018. 


\section{DAFTAR PUSTAKA}

Depdiknas. 2006. Panduan Pengembangan Pembelajaran IPA Terpadu, SMP/MTs. Jakarta: Pusat Kurikulum Balitbang Diknas. Tersedia di http://tedjo21.files.wordpress.com/2009/09/01-model-ipa-terpadu-smp.pdf (diakses pada tanggal 1 Oktober 2011).

Septiadiah. 2011. Percobaan Efek Foto Listrik. Tersedia di https://septiadiah.files.wordpress.com/2011/10/radiasi-1-percobaan-efekfoto-listrik.pdf (diakses pada tanggal 27 Febuari 2018).

Suseno, N, dan Riswanto. 2017. Sistem Pengelolaan Laboratorium Fisika Untuk Mewujudkan Pelaksanaan Pratikum Yang Efisien. Jurnal Pendidikan Fisika Universitas Muhamaddiyah Metro Vol.V.No.1, Hal. 76-86. 